\title{
Prolonged hemiballism after the remission of non-ketotic hyperosmolar syndrome
}

\author{
Yi-Chun Lin, ${ }^{1}$ Yen-Chung Lin ${ }^{2}$ \\ ${ }^{1}$ Department of Internal Medicine, Taipei City Hospital Ren-Ai branch, Taipei, Taiwan; \\ 2Department of Internal Medicine, School of Medicine, College of Medicine, Taipei Medical University Hospital, Taipei, Taiwan
}

Correspondence toDr Yen-Chung Lin, yclin0229@tmu.edu.tw

\section{DESCRIPTION}

A 78-year-old Taiwanese woman presented with polyuria. She denied history of type 2 diabetes mellitus, or cerebral vascular disease. In examinations, the skin turgors were dry. The laboratory data revealed that serum glucose level was $45.34 \mathrm{mmol}$ per litre, sodium level was $133 \mathrm{mmol}$ per litre, haemoglobin A1c was $13.5 \%$ and serum osmolarity was $308 \mathrm{mmol}$ per litre. The serum ketone body was negative. However, after 1 week, a sudden onset of involuntary dyskinesia over left side of limbs (video 1) occurred. The serum sodium level was $136 \mathrm{mmol}$ per litre, and serum glucose levels was $10.3 \mathrm{mmol}$ per litre. She had no other abnormality which could explain the movement disorder. The CT of brain showed bilateral high signals in striatum, (figure 1) and the MR of brain with gadolinium enhanced T1-weighted images displayed bilateral

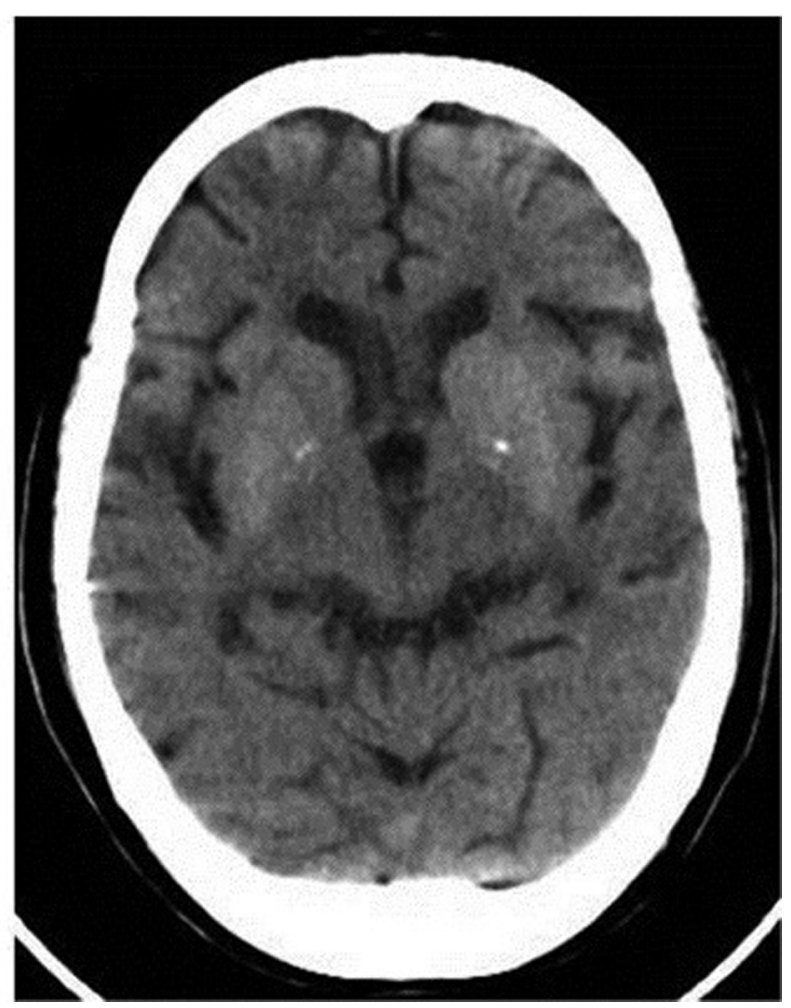

Figure 1 The CT of brain showed bilateral high signals in striatum local high-signals of globus pallidus (figure 2 with red arrow). The symptoms continued but ameliorated after oral risperidol for 2 weeks. Hemiballism is a reversible but rare disorder primarily affecting older Asian diabetic patients during hyperglycaemic crises. ${ }^{1}$ Although traditional hemiballism related to hyperglycaemic states correlates with a contralateral hypertensity T1-weighted MR image over striatum, bilateral involvement might subacutely develop beyond the episode of hyperglycaemia. ${ }^{2}$ Rapid correction of diabetic ketoacidosis may also cause the delayed hemiballism and central pontine myelinolysis. ${ }^{3}$ Recently, a reversible ischaemic insult over striatum potentiated by hyperglycaemia could be detected by spectroscopy. Early detection of ischaemic insults of stratium are keys to prevent long-term damage after episodes of hyperglycaemia.

Video 1 Involuntary dyskinesia focusing on left upper limb in a 78-year-old woman.

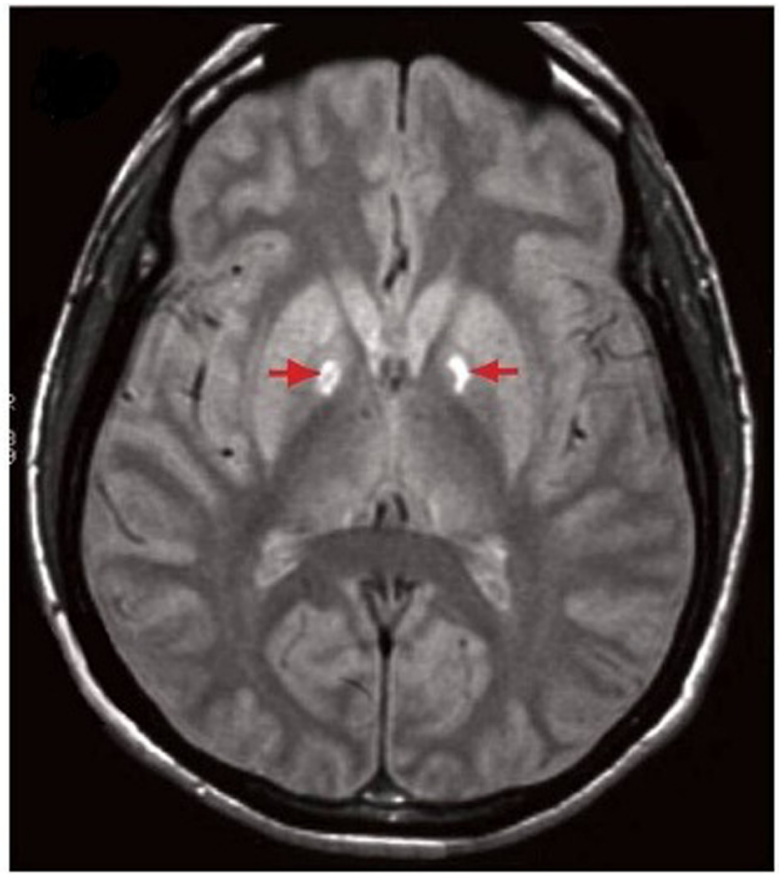

Figure 2 The gadolinium enhanced T1-weighted images of brain MR displayed bilateral localised high-signals over globus pallidus (red arrow). 


\section{BMJ Case Reports}

\section{Learning points}

- The rare and bizzard presentations after the recovery of non-ketotic hyperosmolar syndrome lead to us to report this image.

- This reversible phenomenon could be successful treated by anti-psychotic agents.
Patient consent Obtained.

\section{REFERENCES}

1. Lin JJ, Lin GY, Shih C, et al. Presentation of striatal hyperintensity on T1-weighted MRI in patients with hemiballism-hemichorea caused by nonketotic hyperglycemia: report of seven new cases and a review of literature. J Neurol 2001;248:750-5.

2. Ahlskog JE, Nishino H, Evidente VG, et al. Persistent chorea triggered by hyperglycemic crisis in diabetics. Mov Disord 2001;16:890-8.

3. Duker AP, Espay AJ. Images in clinical medicine. Hemichorea-hemiballism after diabetic ketoacidosis. N Engl J Med 2010;363:e27.

Competing interests None.

This pdf has been created automatically from the final edited text and images.

Copyright 2012 BMJ Publishing Group. All rights reserved. For permission to reuse any of this content visit

http://group.bmj.com/group/rights-licensing/permissions.

BMJ Case Report Fellows may re-use this article for personal use and teaching without any further permission.

Please cite this article as follows (you will need to access the article online to obtain the date of publication).

Lin Y-C, Lin Y-C. Prolonged hemiballism after the remission of non-ketotic hyperosmolar syndrome. BMJ Case Reports 2012;

10.1136/bcr.01.2012.5627, Published XXX

Become a Fellow of BMJ Case Reports today and you can:

- Submit as many cases as you like

- Enjoy fast sympathetic peer review and rapid publication of accepted articles

- Access all the published articles

- Re-use any of the published material for personal use and teaching without further permission

For information on Institutional Fellowships contact consortiasales@bmjgroup.com

Visit casereports.bmj.com for more articles like this and to become a Fellow

Keep up to date with all published cases by signing up for an alert (all we need is your email address) http://casereports.bmj.com/cgi/alerts/etoc 